\title{
Whose Autonomy is it anyway? Freedom of Contract, the Right to Work and the General Principles of EU Law
}

Version accepted 27 September 2019

\section{Final version to be published in the Industrial Law Journal}

\author{
https://academic.oup.com/ili
}

\section{Niall O'Connor*}

\section{Introduction}

Just how significant is the freedom of contract found in article 16 of the EU Charter of Fundamental Rights (the Charter) for the Union's regulatory clout? Rarely has such an innocuous - indeed downright uninspiring - provision generated such controversy. Yet, for the first half of its existence as a legally effective fundamental right, few could have foreseen that article 16 would soon be at the centre of debates surrounding the precise place of business freedoms within EU law. All of this has changed in the wake of a number of controversial decisions in the employment context, in which the Court of Justice of the EU (CJEU) relied on article 16 to undermine the effectiveness of employee-protective legislative rights. ${ }^{1}$ These developments garnered criticism from a number of commentators, who saw a radical turning point in the CJEU's treatment of contractual autonomy. ${ }^{2}$ It is argued here that these employment law judgments are not simply outliers, but rather they are likely to represent something more fundamental within the constitutional architecture of the Union, with implications for the EU's ability to protect and promote social values.

This article demonstrates through an analysis of the case law and reliance on the notion of 'fundamental contradiction' in Critical Legal Studies (CLS) that existing arguments as to the

\footnotetext{
* University of Essex, email n.oconnor@essex.ac.uk. Thanks are due to Donald Nicolson, Simon Deakin and the anonymous reviewers for their feedback. All errors remain my own.

${ }^{1}$ Case C-426/11 Alemo-Herron ECLI:EU:C:2013:521; Case C-201/15 AGET Iraklis ECLI:EU:C:2016:972 56.

2 Stephen Weatherill, 'Use and Abuse of the EU's Charter of Fundamental Rights: On the Improper Veneration of "Freedom of Contract", (2014) 10 ERCL 167, 177; Jeremias Prassl, 'Business Freedoms and Employment Rights in the European Union' (2015) 17 CYELS 189; Stefan Giubboni, 'Freedom to Conduct a Business and EU Labour Law' (2018) EuConst 172, 189.
} 
use of article 16 as a radical tool in the employment context have been both exaggerated and underplayed. In particular, the argument that article 16 conflicts with the CJEU's pre-existing case law on freedom of contract is shown to be much more ambiguous than at first sight. ${ }^{3}$ CLS arguments have largely been absent from debates surrounding freedom of contract in EU law and employment lawyers have generally paid scant attention to the CLS idea of fundamental contradiction, despite its clear implications for the (ir)reconcilability of economic and social values. By disrupting the existing narrative as to the effects of article 16, an issue, which appears to be confined to employment law, is shown to raise broader questions as to the place of social rights considerations in EU law more generally. Determining the place of contractual autonomy within the employment context is also imperative to the proper understanding for employers, employees and policy makers of the regulatory reach of significant sources of EU employment legislation.

Although illustrated using employment law concepts, the question of the precise influence of article 16 has significance for the wider framework of EU law beyond the employment context. Debates as to the extent of the influence of article 16 are also likely to reach into the Union's new governance tools, notably the European Semester, European Monetary Union (EMU) and the nascent Pillar of Social Rights. Despite this, generalist EU lawyers have paid very little attention to the CJEU's use of article 16 in the employment context. This can partly be explained by the fact that the most controversial cases to date have been confined to rather technical areas of EU employment law, including the transfer of undertakings and collective redundancies.

To an extent, the conflict between economic and social aspects of integration has been a perennial question in EU law, but the granting of legal effect to the Charter has thrown an added constitutional or rights dimension into the mix. Resisting the strength of contractual autonomy as a Charter right is likely to require a constitutional solution. The solution posited here is to be found in the general principles of EU law. First, it may be possible to return to the approach adopted in the CJEU's early case law on business freedom as a general principle, in which the concept was usually defeated. Second, it is argued that employees can match the employer's freedom of contract by raising autonomy arguments of their own, in the form of the freedom to pursue a profession as a general principle and the right to work found in article

\footnotetext{
${ }^{3}$ Jeremias Prassl, 'Freedom of Contract as a General Principle of EU Law?' (2013) 42 ILJ 434.
} 
15 of the Charter. The right to work may prove to be the strongest counterweight to the challenges posed by article 16 to the continued potency of EU employment regulation. The question of the precise relationship between the Charter and the general principles is also an issue that will come to the fore post-Brexit. The EU (Withdrawal) Act 2018 makes clear that the Charter will no longer form part of domestic law post-Brexit, but that the general principles will retain their interpretative function.

Section II sets out the nature of freedom of contract in EU law, including the Charter's potentially far-reaching effects in the employment context. This section then considers the first possible solution to unravelling the alleged inconsistencies in the use of contractual autonomy as a legal concept, namely a return to business freedom as a general principle. CLS is relied on to demonstrate that the differing approaches of the CJEU to the general principles and the Charter are actually reflective of a more fundamental contradiction between individual and communitarian values, a contradiction that makes the emphasis on freedom of contract in article 16 all the more troubling. We then turn to the question of the connection between article 16 and the core fundamental freedoms of EU law. Section III addresses the second solution of raising the right to work and employee autonomy as both a general principle and Charter right as a counterweight to freedom of contract.

\section{The Many Meanings of Freedom Contract in EU Law}

\section{A. The Multiple Visions of Contractual Autonomy}

Before analysing the effects of contractual autonomy as a fundamental right, it is useful to consider what that concept actually means in a broader EU law context. A recurring theme in the literature is the notion that contractual autonomy has a dual purpose. Freedom of contract can be viewed either as an overarching economic principle underpinning all markets-the 'market vision' - or it can be seen as a moral principle, based on the will of individuals - the 'voluntarist' vision of contractual autonomy. ${ }^{4}$ Both of these visions can be found in EU law.

\footnotetext{
${ }^{4}$ Simon Whittaker, 'The Optional Instrument of European Contract Law and Freedom of Contract' (2011) 3 ERCL 372, 373-374.
} 
The fundamental Treaty freedoms represent the market vision, with one of the aims of the Union being to extend market competition and contractual freedom within the internal market. ${ }^{5}$ The idea is that the free movement rules require free choice, which requires contractual autonomy. ${ }^{6}$ This notion is contested and there is nothing inherent in the Treaty to suggest that the fundamental freedoms guarantee freedom of contract. ${ }^{7}$ EU legislation (notably consumer protection legislation) is said to represent the voluntarist vision, being concerned with the consent of the contracting parties (ie the quality of their consent to the terms of the contract). ${ }^{8}$ As explored below, this duality - albeit in a modified form - is also reflected in the notion of freedom of contract as a fundamental right.

Basedow argues that 'the principle of contractual freedom has, since the nineteenth century, developed into a foundational tenet in regard to the regulation of economic activity within all European states'. ${ }^{9}$ However, the extent to which it is protected as a fundamental or constitutional right varies significantly between states. When it came to developing business freedom as an EU right, the CJEU had to turn to the constitutional traditions of the Members States for guidance. Only one Member State, Cyprus, grants a specific constitutional protection to the notion of freedom of contract as opposed to a wider commitment to business freedom. ${ }^{10}$ Looking beyond constitutional protection, different Member States adopt different approaches to conceiving the protection of contractual autonomy. As Micklitz puts it, '[w] hat if this common assumption is no more than a rather superficial "gentleman's agreement", which allows us to communicate whilst maintaining our own preconceptions?'.11

Micklitz notes, for example, that English law has been heavily influenced by utilitarian thinking, linked with the rise of the trading state. English contract law is therefore underpinned by a notion of contractual autonomy, which is seen as a tool to promote free commerce. Under this model, freedom of contract 'means first and foremost the economic freedom to voluntarily

\footnotetext{
${ }^{5}$ Carsten Herresthal, 'Constitutionalisation of Freedom of Contract in European Union Law' in Katja S Ziegler and Peter M Huber (eds), Current Problems in the Protection of Human Rights (Oxford: Hart, 2013) 89, 90.

6 ibid 98.

7 Jacobien W Rutgers, 'The European Economic Constitution, Freedom of Contract and the DCFR' (2000) 5 ERCL 95, 102; Maria Marella, 'The Old and the New Limits to Freedom of Contract in Europe' (2006) 2 ERCL 257, 261.

${ }^{8}$ Whittaker (n 4) 375-376.

9 Jürgen Basedow, 'Freedom of Contract in the European Union' (2008) 6 ERPL 901, 902.

${ }^{10}$ European Agency for Fundamental Rights, 'Freedom to Conduct a Business: Exploring the Dimensions of a Fundamental Right' 28.

11 Hans W Micklitz, 'On the Intellectual History of Freedom of Contract and Regulation' (2015) 4 PennStJLInt'lAff 1.
} 
engage in economic transactions without any risk of statutory interferences'. ${ }^{12}$ Such interference is only permitted to the extent that it solves concrete concerns. English law may therefore be described as liberal, utilitarian and pragmatic. ${ }^{13}$ By way of contrast, French law sees contractual autonomy not merely as a utilitarian tool to promote individual economic benefit. Rather, 'the commitment to a contract is the product of a reasonable decision' ie French law looks to the reason behind the decision, linked to the concept of l'autonomie de la volonté (autonomy of the will) and the political concept of the volonté general (general will). ${ }^{14}$ Interference with freedom of contract is seen as a political counter-project to the concept of contractual autonomy set out in the Civil Code. French law can thus be described as rational and political. For Micklitz, it is not possible to reduce the EU vision of contractual autonomy to a sum of the component Member State approaches. Rather, contractual autonomy in EU law is 'bound to trans-border business and European economic integration'. ${ }^{15}$

The absence of a clear underpinning for contractual autonomy at Union level has, to some extent, been addressed by the Draft Common Frame of Reference (DCRF) for a harmonised EU contract law, which describes contractual autonomy as no more than a 'starting point' ${ }^{16}$ Similarly, the Principes Directeurs explain that the principle of freedom of contract in EU law embraces the freedom to enter a contract, the freedom to select a contractual partner and the freedom of classification and content. ${ }^{17}$ The DCFR also explicitly recognises a number of permissible limits on the contractual autonomy principle, notably the non-enforcement of contracts when one of the parties is in a weak bargaining position or where consent is defective. The emphasis has clearly been on the restrictive nature of freedom of contract in EU law rather than its expansive or pervasive character.

It has already been said that freedom of contract in EU law is not merely a by-product of the approaches adopted by its component Member States. The EU model of freedom of contract is distinct, being tied intimately to the development of the single market and the removal of barriers to trade. This is why Micklitz describes EU freedom of contract as functional and instrumental. Regulation of freedom of contract in the form of minimum (social) standards is

\footnotetext{
12 ibid 14.

13 ibid 16

14 ibid 18.

15 ibid 30.

${ }^{16}$ Principles, Definitions and Model Rules of European Private Law Draft Common Frame of Reference (DCFR)

Outline Edition 65.

${ }^{17}$ Herresthal (n 5) 90.
} 
seen as the price to pay for the internal market. In EU law, the protection and limitation of freedom of contract go hand in hand in the pursuit of cross-border trade. ${ }^{18}$ This conception of freedom of contract also corresponds to market vision described above. The autonomous Union approach to dealing with the concept of contractual autonomy as a fundamental right can be seen in the development of business freedoms as general principles of EU law.

\section{B. Business Freedoms as General Principles}

The general principles of EU law are derived from unwritten rules not contained in the Treaties or secondary legislation. ${ }^{19}$ They function as an aid to interpretation and a ground for review of both EU legislation and Member State legislation falling within the scope of EU law. ${ }^{20}$ The protection of fundamental rights is one such general principle of EU law. ${ }^{21}$ This classification of fundamental rights protection as a general principle is now codified in article 6 of the Treaty on European Union (TEU).

The Explanations attached to the Charter make clear that freedom to pursue an economic activity and freedom of contract, as general principles, are two of the components making up freedom to conduct a business in article 16 of the Charter. Taken together these two components are described here as business freedom as a general principle. For the first element-freedom to pursue an economic activity - the Explanations rely on Nold. ${ }^{22}$ In that case, the CJEU noted that property rights and commercial freedom were indeed general principles of EU law, but '[f]ar from constituting unfettered prerogatives must be viewed in the light of the social function of property and activities protected thereunder. ${ }^{23}$ This case is noteworthy both for the clear recognition that there is a freedom of commerce and for the fact that the CJEU offered no guidance as to what it might consider the 'substance' of this freedom. The term 'freedom to pursue an economic activity', contrary to what the Explanations suggest,

\footnotetext{
${ }^{18}$ Micklitz (n 11) 30.

19 Takis Tridimas, The General Principles of EU Law $2^{\text {nd }}$ ed. (Oxford: OUP, 2006) 302.

${ }^{20}$ Koen Lenaerts and José A Gutiérrez-Fons, 'The Role of the General Principles of EU Law' in Anthony Arnull and others (eds), A Constitutional Order of States? (Oxford: Hart, 2011) 179, 180.

${ }^{21}$ Case C-29/69 Stauder ECLI:EU:C:1969:57.

22 Case C-4/73 Nold ECLI:EU:C:1974:51.

23 ibid para 14.
} 
is not actually used in Nold at all, with the CJEU instead referring to the right 'freely to choose and practice their trade or profession'. ${ }^{24}$

In almost all subsequent cases, the CJEU has been reluctant to allow the freedom to pursue an economic activity as a general principle to defeat competing social or economic goals. ${ }^{25}$ The CJEU has consistently held that freedom to pursue an economic activity is not absolute, but must rather be considered in relation to its social function and provided that any restrictions are proportionate, in the public interest and do not impair the substance of the right. ${ }^{26}$

The first explicit recognition of a freedom of contract as opposed to the more general freedom to pursue an economic activity can be found in Sukkerfabriken. ${ }^{27}$ In that case, the CJEU found that EU legal acts, which restrict contractual freedom, might only be permissible to the extent that the acts themselves give explicit authority for the intervention in private contractual relations, as 'no rules or information are provided on the prescribed procedure, the forms or the competent authorities for the action contemplated, such as would be expected if a restriction were to be placed upon the freedom of contract' ${ }^{28}$ In addition, the CJEU in Spain v Commission held that the authorising act must simply stipulate the exact forms and procedures to be followed by the intervening authority. The CJEU held that 'the right of parties to amend contracts concluded by them is based on the principle of contractual freedom and cannot, therefore, be limited in the absence of [Union] rules imposing specific restrictions in that regard' ${ }^{29}$

On the face of it, it is difficult to track this vision of freedom of contract as a general principle onto the multiple approaches to freedom of contract identified earlier. It certainly does not neatly correspond to either the EU's market or voluntarist visions of contractual autonomy, nor is it directly reflective of Micklitz's functional description of freedom of contract in EU law. However, it bears a close resemblance to the English liberal approach to freedom of contract, which holds that the state can only act to the extent that it has been given legal authority.

\footnotetext{
24 ibid.

${ }^{25}$ Case C-230/78 Eridania ECLI:EU:C:1979:216; Cases C-154/04 and C-155/04 Alliance for Natural Health para 123; Case 265/87 Schräder ECLI:EU:C:1989:303 para 15; Case C-200/96 Metronome ECLI:EU:C:1998:172 para 21; Case C-280/93 Germany v Council ECLI:EU:C:1994:367 para 78; Case C-177/90 Kühn ECLI:EU:C:1992:2 para 16; Case C-210/03 Swedish Match ECLI:EU:C:2004:802 para 72.

${ }^{26}$ Cases C-184/02 and C-223/02 Spain and Finland ECLI:EU:C:2004:497.

${ }^{27}$ Case C-151/78 Sukkerfabriken ECLI:EU:C:1979:4.

28 ibid para 20.

${ }^{29}$ Case C-240/97 Spain ECLI:EU:C:1999:479 para 99.
} 
Taken as a whole, the case law on business freedom as a general principle, far from representing a comprehensive statement of that freedom, rather consists of a selective approach. It is also clear that freedom to pursue a commercial activity, freedom of contract and free competition cannot be the only elements making up a freedom to conduct a business. Such a freedom should also include other aspects such as the right to own property and the right to work, which has also been recognised as a general principle, as can be seen from the case law above and which is considered further below in Section III.

\section{Freedom of Contract as a Fundamental Right}

According to article 16 of the Charter: 'The freedom to conduct a business in accordance with Union law and national laws and practices is recognised'. Prassl has distinguished between two aspects of freedom of contract as a fundamental right in article 16, namely freedom of contract as an overarching constitutional concept and freedom of contract as a substantive individual right. ${ }^{30}$ This is largely reflective of the dichotomy generally attributed to freedom of contract in EU law, as set out above. Therefore, when the Charter was granted legal effect, it was expected that the CJEU's approach to business freedom and freedom of contract would continue largely uninterrupted, particularly given the close connection made in the Explanations between the Charter and the general principles. Most of the earlier case law on article 16 did indeed follow the pattern of the general principle of freedom to pursue an economic activity, with arguments based on that freedom largely being unsuccessful. ${ }^{31}$ Many of these cases repeat the standard formula that business freedom may be restricted in the public interest provided that any restriction is proportionate. Some cases refer to the social function of business freedom. ${ }^{32}$ Others omit such a reference, but nevertheless restrict the freedom through the proportionality principle. ${ }^{33}$ In other cases, arguments based on the infringement of article 16 are merely an afterthought, with the General Court expressing its frustration at 'the

\footnotetext{
30 Jeremias Prassl, 'Business Freedoms' (n 2) 193.

${ }^{31}$ Case C-210/00 Käserei ECLI:EU:C:2002:440; Case C-544/10 Deutches Weintor ECLI:EU:C:2012:526; Case C-441/07 Alrosa ECLI:EU:C:2010:377.

${ }^{32}$ Case C-283/11 Sky Österreich ECLI:EU:C:2013:28 para 45.

${ }^{33}$ Case C-70/10 Scarlet Extended ECLI:EU:C:2011:771.
} 
mere abstract reference to such an infringement'. ${ }^{34}$ With the exception of Scarlet Extended, arguments based on the freedom to conduct a business were defeated in all cases. ${ }^{35}$

This restrictive approach to the freedom to conduct a business in article 16 would seemingly change following a number of controversial judgments delivered in the employment context. The first of these cases, Alemo-Herron is said to mark the turning point in the CJEU's approach to contractual autonomy. It is therefore worth dealing with that case in some detail, before considering the CJEU's subsequent reliance on article 16 .

\section{i. The decision in Alemo-Herron}

The question which arose in Alemo-Herron was whether, upon the transfer of a business from one employer to another, the new employer should be bound only by collectively agreed terms in force at the time of the transfer, known as the 'static' approach, or whether they should also be bound by future changes to those collective agreements, known as the 'dynamic' approach. The latter approach was adopted by English courts following the enactment of the original version of the Transfer of Undertakings and Protection of Employment Regulations 2006 (TUPE), which implement the EU's Transfer of Undertakings Directive (TUD). The Directive is a minimum harmonisation measure, meaning that Member States are free to increase the level of protection granted to employees. The dynamic approach is more protective of employees as it ensures that they continue to be covered by the same collective agreements, including future changes to those agreements.

In Alemo-Herron, the company sought to rely on the earlier CJEU decision in Werhof to challenge the continuation of a collective agreement, as they had not been involved in the negotiation of that agreement. ${ }^{36}$ In that earlier case, the CJEU found that the dynamic approach was not necessitated by the TUD, but neither was it prohibited. As a starting point, AG Cruz Villalón noted that the effect of Werhof was clearly to rule out the possibility that the TUD required Member States to permit the transfer of dynamic clauses referring to future collective agreements. ${ }^{37} \mathrm{He}$ then noted that Parkwood, unlike Freeway (the company in Werhof), had taken over an undertaking that was originally in the public sector. Consequently, Parkwood could neither take part in nor indirectly influence the collective bargaining process that takes

\footnotetext{
${ }^{34}$ Case T-17/12 Hagenmeyer and Hahn ECLI:EU:T:2014:234 para 122.

35 Case C-70/10 Scarlet Extended.

${ }^{36}$ Case C-499/04 Werhof ECLI:EU:C:2006:168.

${ }^{37}$ AG opinion in Case C-426/11 Alemo-Herron ECLI:EU:C:2013:82 para 19.
} 
place within the National Joint Council (NJC), which is exclusively a body for local government collective bargaining. ${ }^{38}$

The AG concluded that 'in the context of the transfer of an undertaking, there is no obstacle to Member States allowing a transfer of dynamic clauses referring to future collective agreements'. ${ }^{39}$ The AG then highlighted the employer's freedom of contract found in article 16. ${ }^{40}$ Despite this, he went on to uphold the dynamic approach so long as it was not unconditional or irreversible. ${ }^{41}$

By contrast, the CJEU preferred to adopt the static approach, holding that where a transferee does not have the opportunity to participate in negotiations that are concluded after the date of transfer, the outcome of the negotiations should not be binding. ${ }^{42}$ The CJEU noted that a balance had to be struck, with 'due weight' being given to the freedom of contract of employers:

[i]t is apparent that, by reason of the freedom to conduct a business, the transferee must be able to assert its interests effectively in a contractual process to which it is party and to negotiate the aspects determining changes in the working conditions of its employees with a view to its future economic activity. ${ }^{43}$

The dynamic approach to collectively agreed terms was therefore not valid. To hold otherwise, the Court reasoned, would be to reduce employer freedom 'to the point that such a limitation is liable to adversely affect the very essence of its freedom to conduct a business' ${ }^{44}$

It could have been argued that the transferee employer had consented to the transfer and had done so under the existing terms and conditions, which should have included the dynamic clause. For the CJEU, however, this consent was defective because the new employer was not capable of taking part in the negotiating process. Here, the 'voluntarist' and 'market' visions of freedom of contract in EU law coincide, with the CJEU also (albeit tacitly) expressing concern that allowing the dynamic approach would be to impede or discourage the acquisition of undertakings, particularly in the context of privatisation.

The CJEU's approach to contractual autonomy in Alemo-Herron goes beyond the English liberal conception of that freedom. Here, there was quite clearly authority provided in law for

\footnotetext{
38 ibid.

39 ibid para 20.

40 ibid para 46.

${ }^{41}$ Case C-426/11 Alemo-Herron para 58.

42 ibid para 37.

43 ibid para 33.

44 ibid para 35.
} 
the restriction on the employer's freedom of contract. The restriction also provided a solution to a concrete problem - one of the permissible restrictions on freedom of contract according to the liberal theory. Alemo-Herron much more closely aligns to the idea that freedom of contract in EU law is functional ie it is about the construction and maintenance of an internal market. As will be explained below, CLS might help to explain the strong notion of freedom of contract suddenly espoused in Alemo-Herron.

The judgment is clearly not consistent with the CJEU's earlier decision in Werhof. ${ }^{45}$ Moreover, it ignores the fact that article 8 TUD expressly permits Member States to increase the level of protection granted to employees. ${ }^{46}$ The CJEU also granted unnecessary weight to freedom of contract within article 16, which after all provides that the 'freedom' (not the right) to conduct a business is 'recognised' (not guaranteed). Perhaps the most significant criticism of the judgment is that the CJEU's use of article 16 in Alemo-Herron marks a radical departure from the pre-existing case law on business freedom as a general principle. ${ }^{47}$ The reality of the relationship between article 16 and the general principles is much more nuanced.

ii. Compatibility of business freedom as a fundamental right with the general principles

From the case law on freedom to pursue an economic activity as a general principle, it is possible to discern a number of criteria which must be considered when assessing the compatibility of legislation with that general principle. First, the freedom is not absolute, but must be considered in relation to its social function. Second, any restrictions must be proportionate. Third, restrictions must be in the public interest. Finally, any restrictions must not impair the very substance of the freedom. Each of these elements will now be addressed in turn.

a. The social function of commercial freedom

Despite the CJEU's glossing over of the term in its judgments, the concept of the social function of commercial freedom hides a far from universally accepted notion of the limits to be placed on property rights. Foster and Bonilla remark that 'the classical liberal conception of property dominates the modern legal and political imagination. The idea that property is a subjective

\footnotetext{
${ }^{45}$ Case C-499/04 Werhof para 37.

${ }^{46}$ Marija Bartl and Candida Leone, 'Minimum Harmonisation after Alemo-Herron: The Janus Face of EU Fundamental Rights Review' (2015) 11 EuConst 140.

47 Jeremias Prassl, 'Freedom of Contract' (n 3).
} 
and nearly absolute right controls the way in which most of the modern law and politics understands this institution'. ${ }^{48}$ There is a vast literature on this liberal conception of property, with the most ubiquitous understanding of the concept deriving from Locke and Hegel whose writings are frequently used to 'justify the private property relations that underpin modern Western society'. ${ }^{49}$ Stone comments that the works of Locke and Hegel, 'signal the two related but distinct bases of conventional property theory; first, that property is a legitimate reward for the enterprise of the sovereign individual; second, that it is through property that we understand the boundaries of the self.${ }^{50}$ Kant goes further in explicitly tying his conception of property to the liberal notion of 'freedom', defined as the absence of constraint. ${ }^{51}$

A common theme connecting critiques of this orthodox position includes the idea that property should be understood in its social and political context. ${ }^{52}$ For example, Duguit has argued that property is not a right but rather a social function. According to this view, 'property has internal limits - not just external ones as in the case of the liberal right to property'. ${ }^{53}$ It is unclear whether this is the theory the CJEU had in mind when it proclaimed that property and business rights must be considered in relation to their 'social function'. Indeed, Kant, who explicitly draws a link between property and liberty, also views property as having a form of social function. For Kant, property and freedom are not merely coextensive. Rather, freedom is the basis for property. As Stone remarks, "property is not a pure metaphysical bond between an individual and an object; it concerns a social connection with others' ${ }^{54}$ In other words, it has a social or relational function.

It is doubtful that the CJEU intended to revisit the liberal foundations of property in its judgments on the general principles. It is equally unclear what the CJEU meant when it said that property has a social function. The absence of explicit reasoning in the article 16 jurisprudence is equally regrettable. In those cases, not only did the CJEU fail to consider the competing social goals which might limit business freedom as a fundamental right, but it also manifestly ignored the potential internal limitations on this freedom, in the form of its social

\footnotetext{
48 Sheila R Foster and Daniel Bonilla, 'Symposium on the Social Function of Property: A Comparative Law Perspective' (2011) 80 Fordham LRev 101.

49 Matthew Stone, 'Roberto Esposito and the Biopolitics of Property Rights' 24 (2015) S\&LS 381, 383.

50 ibid 384.

51 ibid.

52 ibid 385.

${ }^{53}$ Léon Duguit, Las Transformaciónes Del Derecho Público Y Privado (Buenos Aires: Editorial Heliasta, 1975) 179.

${ }^{54}$ Stone (n 49) 389.
} 
function; a conception (however ambiguous) of property rights it apparently subscribed to not long ago.

This confusion in relation to the freedom to pursue an economic activity is thrown into even sharper focus when we consider that the case law on freedom of contract as a general principle makes no mention whatsoever of that right being restricted by any social function. Indeed, in those cases, the CJEU gave no indication as to the permissible limits on contractual autonomy. In Spain, the CJEU merely held that 'the right of parties to amend contracts concluded by them is based on the principle of contractual freedom and cannot, therefore, be limited in the absence of [Union] rules imposing specific restrictions in that regard'. ${ }^{5}$

The CJEU went on to note that 'provided that the purpose of the contractual amendment is not contrary to the objective pursued by the applicable [Union] rules and does not involve any risk of fraud, such an amendment cannot be regarded as unlawful' ${ }^{56}$ In this case, the CJEU tacitly accepted the possibility of limiting the principle of contractual autonomy in EU law, but provided only fraudulent activity and the Union's objectives as specific examples of such limitations. In Sukkerfabriken, the CJEU was equally reticent. In that case, the CJEU held that the legislation in question provided no rules 'on the prescribed procedure, the forms of the competent authorities for the action contemplated, such as would be expected if a restriction were to be placed upon freedom of contract' ${ }^{57}$

Clearly, the cases dealing specifically with freedom of contract do not refer to the concept of a social function, nor is there any reference in those cases to the jurisprudence on freedom to pursue an economic activity as a general principle from which an implicit restriction on freedom of contract based on its social function could be inferred. The same is true of AlemoHerron, which makes no reference at all to a social function. Zuckerfabrik, a case that represents the modern statement of business freedom as a general principle, also makes no mention of that freedom having any social function. ${ }^{58}$ Tellingly, this is one of the cases relied on by the AG in Alemo-Herron.

b. Restrictions must be proportionate

\footnotetext{
${ }^{55}$ Case C-240/97 Spain para 99.

56 ibid para 100.

${ }^{57}$ Case C-151/78 Sukkerfabriken para 20.

${ }^{58}$ Cases C-143/88 and C-92/89 Zuckerfabrik ECLI:EU:C:1991:65.
} 
In its jurisprudence on the freedom to pursue an economic activity as a general principle, the CJEU took as its starting point that restrictions on that right were prima facie lawful. ${ }^{59}$ In Alemo-Herron, the CJEU reversed this starting point, requiring justification for restricting business freedom from the outset. ${ }^{60}$

What we learn from the case law on the freedom to pursue an economic activity is that the CJEU tends to grant a wide margin of discretion to the Union legislature, particularly in fields involving complex and sensitive social, political and economic choices. ${ }^{61}$ No such discretion is granted to the Member States in Alemo-Herron. In fact, in that case, the CJEU showed insensitivity towards the domestic labour traditions of the United Kingdom despite the fact that the TUD was a minimum harmonisation measure.

Another point of note is that in its earlier case law, the CJEU showed little concern for the actual impact of a measure on the traders' business freedoms. ${ }^{62}$ In Alemo-Herron, the CJEU showed greater concern for the effect of the interpretation of the TUD on individual traders, holding that 'a dynamic clause referring to collective agreements negotiated and agreed after the date of transfer of the undertaking concerned that are intended to regulate changes in working conditions in the public sector is liable to limit considerably the room for manoeuvre necessary for a private transferee to make such adjustments and changes' ${ }^{63}$ The CJEU fails to set out precisely what this impact would be. Once again, if we look to the case law on freedom of contract as a general principle, there is no engagement with the proportionality issue at all.

c. Restrictions must be in the public interest

In its case law on freedom to pursue an economic activity as a general principle, the CJEU took a wide approach to this issue, with relatively mundane restrictions of commercial autonomy being held to be in the public interest. ${ }^{64}$ In Alemo-Herron, there was no mention of a wider public interest. Admittedly, given the context, there was a discussion of the interests of employees and therefore implicitly the interests of society in regulating the employment relationship. ${ }^{65}$

\footnotetext{
${ }^{59}$ Cases C-154/04 and C-155/04 Alliance for Natural Health para 52; Case C-44/79 Hauer ECLI:EU:C:1979:290 para 23.

${ }^{60}$ Case C-426/11 Alemo-Herron paras 29, 31.

${ }^{61}$ Cases C-154/04 and C-155/04 Alliance for Natural Health.

${ }^{62}$ Case C-280/93 Germany v Council.

${ }^{63}$ Case C-426/11 Alemo-Herron para 28.

${ }^{64}$ See for eg Case C-210/03 Swedish Match.

${ }^{65}$ Case C-426/11 Alemo-Herron para 25.
} 
Again, however, if we look to the case law on freedom of contract as a general principle, there is no explicit mention of the public or general interest. Spain refers to the Union's financial interest, ${ }^{66}$ whereas Sukkerfabriken speaks of the objectives of the common organisation of the market. ${ }^{67}$

d. Restrictions must not impair the substance of the freedom

In the case law on freedom to pursue an economic activity, the CJEU consistently found that the essence or core of that principle has been left untouched. ${ }^{68}$ Restrictions were usually justified despite their financial impact. The CJEU viewed such interference as restricting the modalities of the exercise of economic freedom as opposed to interference with the right itself. In Alemo-Herron, however, the CJEU held that what appeared on its face merely to be an issue of how the right was exercised turned out to affect the very core or essence of that right. ${ }^{69}$ The case law on freedom of contract as a general principle also does not refer to a core or essence of the right at all.

What we can take from this analysis of the case law on freedom of contract and the freedom to pursue an economic activity as both a fundamental right and a general principle is that it is really rather difficult to say whether the CJEU's recent use of article 16 marks a significant departure from this earlier jurisprudence. In certain respects, Alemo-Herron does indeed depart from earlier case law on the general principles, especially that on freedom to pursue an economic activity. In other respects, however, it actually reflects the inconsistencies in that case law, including the fact that different language is used when describing limitations to freedom of contract and freedom to pursue an economic activity.

It might therefore be argued, that the apparent divergence between the general principles and the Charter is not a contradiction, but rather a 'fundamental contradiction' understood in CLS terms. Relying on CLS allows us to demonstrate that the CJEU's use of article 16 in cases such as Alemo-Herron is simultaneously uncontroversial and yet hides a deeper contradiction within

\footnotetext{
66 ibid para 37.

${ }^{67}$ Case C-151/78 Sukkerfabriken.

${ }^{68}$ Cases C-154/04 and C-155/04 Alliance for Natural Health para 128; Case C-210/03 Swedish Match para 73.

${ }^{69}$ Case C-426/11 Alemo-Herron para 36.
} 
the concept of contractual autonomy, with potentially more serious implications for the future regulation of the employment relationship.

\section{iii. The meaning of 'fundamental contradiction' in Critical Legal Studies}

The CLS movement seeks to uncover contradictions in the law and to expose its erratic and irrational application, with the aim of bringing about radical or revolutionary social change. ${ }^{70}$ Inconsistencies are said by CLS theorists to undermine coherence and thereby the law's legitimacy. A key aim, then, of analysing inconsistencies in the law is to highlight that the contradictions of liberal legalism and the ideology it generates, consist of rival social visions. In other words, CLS rejects the idea that the law is coherent and predictable, arguing instead that legal decisions are dependent on the outcome of a series of contradictory principles, which reflect irreconcilable fundamental contradictions within the law. These contradictions expose the reality that the law is not a coherent set of principles that can be systematically tied together. The main value of relying on CLS in this article is to tease out the meaning of 'contradiction' in the law and also to demonstrate that the liberal concept of freedom of contract has been used to embed the status quo, which any social restrictions in the name of rebalancing were always likely to struggle to overcome.

There are many views on the meaning of contradiction within CLS. The most ubiquitous conception comes from Kennedy, who argues that all contradictions in the law flow from one fundamental contradiction, which is the idea that 'relations with others are both necessary and incompatible with our freedom'. ${ }^{71}$ In other words, although liberalism espouses individual freedom, we rely on the law and the institutions of the state to ensure that individual freedom is not abused. In turn, as well as protecting our freedom, these state institutions may threaten that same freedom. Thus, Kennedy sets up an irresoluble fundamental contradiction between freedom (the individual) and the community. Kennedy argues that the contradiction between individualism/self/autonomy and community/others/collective security is at the heart of all legal problems. ${ }^{72}$ The idea is that while, in theory, it is possible to interfere with individual autonomy just enough so that it protects overall freedom, in practice the decision as to the correct balance between the freedom of the individual and overall freedom will vary from place

\footnotetext{
${ }^{70}$ Denise Meyerson, 'Fundamental Contradictions in Critical Legal Studies' (1991) 11 OJLS 439; Alan Hunt, 'The Theory of Critical Legal Studies' (1986) 6 OJLS 1.

${ }^{71}$ Duncan Kennedy, 'Structure of Blackstone's Commentaries' (1979) 28 BuffaloLR 209, 213.

72 Duncan Kennedy, 'Form and Substance in Private Law Adjudication' (1976) 89 HarLRev 1685; Roberto Mangabeira Unger, 'The Critical Legal Studies Movement' (1983) 96 HarLRev 563.
} 
to place, era to era and judge to judge. For this reason, it will always be possible to point to conflicts or contradictions between individual judgments. The fundamental contradiction tells us that consistency is never really possible.

Fundamental contradictions have also been identified within freedom of contract itself. Mensch argues that freedom of contract seeks to protect our freedom to enter mutually beneficial arrangements, while simultaneously holding us to those arrangements even when they cease to be beneficial. The contradiction here is that freedom of contract leads to coercion. ${ }^{73}$ Unger, in his critical analysis of contract law doctrine also identifies freedom of contract as one of its underlying principles. Unger's understanding of this principle is that 'the parties must be free to choose the terms of their agreement. Save in special cases, they will not be second-guessed by a court, not least as long as they stay within the ground rules that defined a regime of free contract' ${ }^{74}$ This principle can be met with a counter principle (which Unger suggests has been marginalised to date), namely the idea that unfair bargains should not be enforced. ${ }^{75}$ We will come back to this notion of counter principle in the discussion of the right to work below.

It is clearly possible to track the idea of fundamental contradiction onto contractual autonomy in EU law. The concept of freedom of contract reflects the individualism/freedom limb of the fundamental contradiction. ${ }^{76}$ This limb is illustrated in general EU law via the DCFR which, as discussed, views freedom of contract as embracing the right to enter a contract, to select the other party and to classify the contract. Essentially, we should be free to make our own decisions without any interference on altruistic, protectionist or paternalistic grounds. The second limb of the contradiction is that the law does indeed interfere with freedom of contract in order to protect the weaker party. Again, the DCFR sets out a number of permissible restrictions on contractual autonomy in EU law, most notably the non-enforcement of contracts when one of the parties is in a weak bargaining position or where consent is defective. The same contradiction is reflected in the concept of freedom of contract as a fundamental right in EU law. On the one hand, we have the recognition that contractual autonomy and the freedom to pursue an economic activity are rights to be protected. On the other hand, we have limitations placed on those rights, for example through the recognition of a competing social function. More broadly, we have already seen that that the concept of freedom of contract within article

\footnotetext{
${ }^{73}$ Betty Mensch, 'Freedom of Contract as Ideology' (1980-81) 33 StanLRev 753.

${ }^{74}$ Unger (n 72) 625.

75 ibid 632.

${ }^{76}$ Mark Kelman, A Guide to Critical Legal Studies (Cambridge: HUP, 1987).
} 
16 itself has multiple and potentially contradictory aims. It can be viewed as an individual right, promoting autonomy (voluntarist perspective) or it can be characterised as a tool in the construction of an economic constitution for Europe (market perspective). The latter requires the promotion of business freedom while the former requires its limitation through legislation.

What CLS (or at least Unger-whose membership of CLS is admittedly controversial) teaches us is that, rather than overthrowing the underlying theory (for example, freedom of contract), it is possible to modify existing doctrines to accentuate and develop an alternative image of social life, until such time as the counter principle becomes dominant. ${ }^{77}$ As such, rather than being incoherent or contradictory, a legal doctrine might be described as adaptable, allowing judges a necessary flexibility in deciding between competing demands. ${ }^{78}$ Such a process may 'leave a messy line of precedents behind that can be seized upon by lurking critical theorists and pronounced incoherent'. ${ }^{79}$ Viewed in this way, the apparent conflict between freedom of contract as a fundamental right and freedom of contract as a general principle may represent a reflection of the ebb and flow of the emphasis placed on business freedom within EU law more generally as discussed at (v) below. This also reflects the more general ebb and flow of the relationship between individualism (freedom of contract and capitalism) and altruism. ${ }^{80}$

Feynman and Gabel point out that despite the increased emphasis on the altruistic/collective limb of the fundamental contradiction throughout the $20^{\text {th }}$ century, the old freedom of contract principles deriving from the $19^{\text {th }}$ century still survive, thereby contributing to the law's incoherence. ${ }^{81}$ The new approach does not eradicate the old and the fundamental contradiction survives. In this way, contradictions in the law are reflective of the values that are emphasised at a particular point in time. This reflects the argument made by Unger that one side of the contradiction (or duality as he puts it) tends to be favoured over the other. ${ }^{82}$ CLS argues that when individualism is pitted against communitarianism, it is usually the former that prevails. This is the liberal capitalist status quo identified by CLS as the main target for challenge.

Liberal theory itself also recognises the potential for contradiction and incoherence in the law. The main difference between liberal theory and CLS is that the former will seek to create

\footnotetext{
${ }^{77}$ Hunt (n 70).

78 ibid 33,36 .

79 ibid 36.

${ }^{80}$ Feinman and Gabel, 'Contract Law as Ideology’ in David Kairys (ed), The Politics of Law (New York: 1982, Basic Books) ch 8.

81 ibid.

${ }^{82}$ Unger (n 72).
} 
coherence by identifying and then attempting to rationalise or remove contradictions, whereas the latter views the contradictions as being inherent in the legal system and therefore irresolvable. Of course, we are entitled to expect a minimum standard of rationality from the judiciary. This does not mean that courts cannot change their understanding of a particular legal concept, as long as it advances valid arguments to support its decision. CLS goes further, arguing that the idea of consistency or coherence is mythological, being no more than a rhetorical device, creating a veneer of legitimacy for judicial decision-making. It is therefore unwise to expect consistency if the basic ideas underlying the law are in conflict. This is all the more so when we consider the peculiarities of the CJEU's reasoning process and the absence of a doctrine of precedent. ${ }^{83}$ For CLS scholars, this must be particularly true of rights, which are 'defined on too abstract a level to be helpful in resolving the claims presented in particular'. ${ }^{84}$

One does not necessarily have to accept the entirety of CLS's critique of liberal legalism to recognise its potential value in highlighting the wider fundamental contradictions within freedom of contract that can help to explain these inconsistencies between the general principles and article 16. Of course, it is also possible to view what appear to be contradictions in the law as no more than 'competing' principles. This was certainly the view of Dworkin in his criticism of CLS when he said that '[t]wo abstract principles (...) could live together comfortably (...) even though they sometimes conflict' ${ }^{85}$ From a doctrinal perspective, the above discussion sought to show that rather than necessarily being contradictory, the approaches adopted by the CJEU in the general principles and article 16 cases may simply be viewed as competing visions of freedom of contract as developed over time and in different contexts. The idea that the general principles and the Charter might represent competing rather than necessarily contradictory concepts of freedom of contract also raises the question of whether the Charter and the general principles will actually continue to represent two distinct sources of EU fundamental rights.

iv. The relationship between the general principles and the Charter

\footnotetext{
${ }^{83}$ Niall O'Connor, 'Interpreting Employment Legislation through a Fundamental Rights Lens: What's the Purpose?' (2017) 8 ELLJ 193.

${ }^{84}$ Mark Tushnet, 'Critical Legal Studies: An Introduction to its Origins and Underpinnings' (1986) 36 JLegEd $505,516$.

${ }^{85}$ Ronald Dworkin, Law's Empire (Cambridge: HUP, 1986) 271.
} 
The intimate link between the general principles and the Charter is made clear by the Explanations, which confirm that many of the Charter's provisions derive from pre-existing general principles. More broadly, article 6 TEU also confirms that far from being a mere source of Charter rights, the general principles and the Charter actually enjoy the same constitutional status. However, we are given no indication as to the precise relationship between these sources. If the Charter was merely intended to codify or render more visible existing EU fundamental rights, this begs the question of whether the Charter replaces the general principles or whether the two sources are now co-terminous and mutually dependent.

Using the Charter as the CJEU's primary point of reference may be to overlook the fact that the general principles themselves have been explicitly recognised as having constitutional status by their inclusion in the Treaties. Nevertheless, cases dealing with article 16 confirm that the Charter is to be the principal source of EU fundamental rights. We saw that in AlemoHerron, the CJEU did not refer to its existing jurisprudence on contractual autonomy as a general principle. Given the lack of explicit prioritisation of the Charter, it is perhaps the case that the CJEU merely uses the Charter as a starting point from a purely practical perspective. In any case, the Charter's provisions, which are often indeterminate in themselves, will continue to be informed by the general principles. ${ }^{86}$ Furthermore, the general principles will continue to have a role outside the Charter, serving to fill gaps in the law and promoting consistent interpretation. ${ }^{87}$ Finally, the CJEU confirmed in Akerberg Franson that the general principles and the Charter enjoy the same scope of application. ${ }^{88}$ The interdependence between the general principles and the Charter is further borne out by the fact that the Charter itself may become a source of general principles. ${ }^{89}$

It is all very well in the abstract stating that the Charter and the general principles will continue to co-exist as sources of fundamental rights, but if a Charter right derives from a pre-existing general principle, it has been argued by some commentators that this has the effect of extinguishing, or at least deprioritising, the general principle. For example, Oliver suggests that 'Article 16 seamlessly replaced the pre-existing fundamental right to conduct a business which had existed as a general principle of Union law' ${ }^{90}$ As already argued, this is not true, as article

\footnotetext{
${ }^{86}$ Tridimas (n 19) 378.

87 ibid 379.

${ }^{88}$ Case C-617/10 Åkerberg Franson ECLI:EU:C:2013:105.

${ }^{89}$ Lenaerts and Gutiérrez-Fons (n 20) 184-185.

${ }^{90}$ Peter Oliver, 'What Purpose does Article 16 of the Charter Serve?' in Ulf Bernitz and others (eds), General Principles of EU Law and European Private Law (The Netherlands: Kluwer, 2013) 281, 283.
} 
16 is made up of diverse components, which have been treated differently by the CJEU in its earlier case law.

The CJEU continues to adopt a pick and choose approach, sometimes referring to earlier case law on the general principles and sometimes ignoring it entirely. Oliver goes on to argue that, even if the general principles and article 16 were different concepts, there would be "no point in maintaining in existence two overlapping but slightly different fundamental rights'. ${ }^{91}$ This overlooks the fact that the Explanations make clear that the general principles can be used as a guide to the interpretation of article 16. If the content of the general principles and article 16 were homogenous, there would be little point on ever relying on the former.

In addition, the Charter was merely intended to codify existing rights, ie it is a snapshot in time. This cannot preclude the further development and evolution of the general principles, including in a field covered by the Charter. Otherwise, this would create two classes of general principle; one independent of the Charter and the other subsumed by it. No such division is envisaged by the Treaty. The CJEU has also more recently drawn a very clear distinction between the general principles and article 16 by tying the latter provision into the four fundamental freedoms of EU law.

v. Fundamental rights and fundamental freedoms

One of the most controversial judgments handed down in the wake of Alemo-Herron suggests that freedom of contract within article 16 is linked intimately with the freedom of establishment found in article 49 of the Treaty on the Functioning of the European Union (TFEU). In AGET Iraklis, the CJEU had to assess the compatibility of Greek legislation requiring prior authorisation of collective redundancies with both article 16 of the Charter and article 49 TFEU. The CJEU noted that the decision to engage in collective redundancies was a fundamental decision in the life of an undertaking and that, as a result, the legislation at issue was likely to hinder or make less attractive that freedom. Consequently, the measure also hindered or limited the exercise of the freedom to conduct a business in article $16 .{ }^{92}$ This approach reflects the language of Alemo-Herron, where the CJEU found that the dynamic approach excessively interfered with the employer's room for manoeuvre to make adjustments. In both cases, the CJEU was not susceptible to the argument that the employers entered the market or accepted the transfer knowing about the pre-existing restrictions on their contractual

\footnotetext{
91 ibid.

${ }^{92}$ Case C-201/15 AGET Iraklis 56.
} 
autonomy (the dynamic clause in Alemo-Herron and requirement of approval for collective redundancies in AGET Iraklis).

At a first glance, the connection drawn between the freedom of establishment and article 16 should be very worrying from the perspective of those who support a stronger level of protection for workers' rights in the face of competing business freedoms. In Alemo-Herron, the CJEU took as its starting point, the employer's freedom of contract, with the dynamic approach acting as a restriction on that freedom. This is a standard application of the freedom of establishment approach, which is also reflected in AGET Iraklis. The consequence of this approach is that social concerns are viewed as restrictions of the underlying Treaty freedom/freedom of contract. Any derogation from the fundamental freedoms must be interpreted restrictively. This puts social considerations on the back foot from the very outset.

Having said that, the CJEU has often been open to arguments based on the protection of workers, even developing a specific worker protection derogation from the Treaty freedoms. ${ }^{93}$ As Barnard notes, where there is a genuine concern for the protection of workers at national level, the Court will uphold the worker protection justification. ${ }^{94}$ The CJEU has long recognised worker protection as a legitimate derogation allowing Member States to justify national laws providing substantive protection to the weaker party so long as the derogation respected the limits of EU law and did not render the economic freedom illusory. ${ }^{95}$

In cases such as Schmidberger, ${ }^{96}$ the CJEU has demonstrated that where the case is more removed from commercial considerations (in that case, the right to protest), 'the more generous the Court is as regards the available scope for justification and also the breadth of the margin of appreciation' ${ }^{97}$ In other cases such as Viking, the CJEU clearly got the balance wrong, with free movement provisions being used to defeat the right to strike. This was despite the CJEU's recognition that such a right was also a general principle of EU law. ${ }^{98}$ This is likely to be part of broader phenomenon whereby any social dimension to the freedom of movement will of necessity be subject (if not subordinate) to the economic rationale inherent within the Treaty

\footnotetext{
${ }^{93}$ Case C-155/80 Oebel ECLI:EU:C:1981:177.

${ }^{94}$ Catherine Barnard, 'The Worker Protection Justification: Lessons from Consumer Law' in Panos Koutrakos, Niamh Nic Shuibhne and Phil Sypris (eds), Exceptions from EU Free Movement Law (Oxford: Hart, 2016) 108, 110.

95 ibid 113.

${ }^{96}$ C-112/00 Schmidberger ECLI:EU:C:2003:333.

${ }^{97}$ Mark Freedland and Jeremias Prassl, 'Viking, Laval and Beyond: An Introduction' in Mark Freedland and Jeremias Prassl (eds), Viking, Laval and Beyond (Oxford: Hart, 2016) 32.

${ }^{98}$ Case C-438/05 Viking ECLI:EU:C:2007:772 and Case C-341/05 Laval ECLI:EU:C:2007:809.
} 
provisions. Any such economic rationale does not lead to the conclusion that free movement law somehow embodies a principle of contractual autonomy. ${ }^{99}$ Again, drawing on CLS allows us to view this conflict as part of the wider irreconcilable fundamental contradiction between freedom of contract and the need for state intervention and demonstrates that consistency is not achievable.

The real problem lies in the fact that freedom of contract is now being prioritised by the CJEU, while employment rights that potentially restrict that freedom are largely being overlooked. As Unger would put it, the principle is being privileged at the expense of the counter principle. A more substantive view of autonomy envisages legislative intervention as a means of preserving the autonomy of the weaker party (for example, the worker). ${ }^{100}$ To achieve this, it will be necessary to end the conception of legislative intervention as an exception or inherent limitation on contractual autonomy, which is seen as the normal and justified state of affairs. As explained below, some legislative rights are underpinned by fundamental Charter rights with at least nominally equal weight to article 16 . Yet, the CJEU continues to view freedom of contract as the 'right' to be protected, with any regulation of that right requiring justification. This reflects an ongoing problem whereby regulation is seen as a cost on business, which as such interferes with contractual autonomy. Clearly, difficulties in determining the precise content of freedom of contract long pre-date article 16, with the CJEU's recent case law merely continuing a tradition of inconsistency and lack of clarity as to the limits of freedom of contract.

Evidently, employment law is not the only context in which the reach of article 16 might extend. ${ }^{101}$ This is largely due to the position of the Charter at the pinnacle of the Union's hierarchy of norms. This also ties in with the earlier discussion on CLS, which views the fundamental contradiction between the individual and the community as being tilted in favour of the former. Given the privileged constitutional position of freedom of contract, the answer to clarifying its precise regulatory reach requires a much more robust application of the constitutionalised social rights found in the Charter. One such provision is the right to work, which enjoys an equally long pedigree as a general principle. It is also argued here that the right to work has the potential to act a counter principle to freedom of contract in the vein of suggestions made by Unger mentioned above in the discussion of CLS.

\footnotetext{
${ }^{99}$ Gareth Davies, 'Freedom of Movement, Horizontal Effect, and Freedom of Contract' (2012) 3 ERPL 805, 809. ${ }^{100}$ Aurelia Colombi Ciacchi, 'Party Autonomy as a Fundamental Right in the European Union' (2010) 6 ERCL 303.

${ }^{101}$ See Cases C-8/15 to C-10/15 Ledra ECLI:EU:C:2016:701 and Case C-258/14 Florescu ECLI:EU:C:2017:448.
} 


\section{Countering Contractual Autonomy with the Right to Work}

\section{A. The Nature of the Right to Work and its Relationship with Freedom of Contract}

In its case law on the freedom to pursue an economic activity as a general principle, the CJEU drew a connection between business freedom and the freedom to pursue an occupation, with the CJEU recognising that the concepts are related and that both are general principles of EU law. ${ }^{102}$ But, in previous case law, the CJEU has shown a preference for counterbalancing Charter rights with other provisions found in the Charter, rather than with general principles. ${ }^{103}$ A similar concept to the freedom to pursue an occupation is found within the Charter in the form of the right to work in article 15 , which is itself partly derived from the earlier case law on freedom to pursue an economic activity as a general principle.

Article 15(1) provides that '[e]veryone has the right to engage in work and to pursue a freely chosen or accepted occupation'. The language used here is much more robust and rightsoriented than that found in either article 16 or indeed many of the Charter's employment rights. It is for this reason and also for its inclusion in the Freedom Title (the same Title as article 16), that the right to work might be thought to be particularly apt to counterbalance business freedom as a fundamental right. Despite this, the right has so far been over-looked by both litigants and the judiciary. There are a number of reasons for the right to work's absence to date.

First, there is no consensus on the nature and content of the right to work. The right to work could be aimed at achieving full employment and could be seen as guaranteeing the right of every individual to a job. It can also be conceived as a right not only to work, but also to decent work. Finally, the right could be about something broader still, being 'more than freedom from coercion or freedom of occupation [entailing] a more positive dimension - the right to have work (...) and rights in work or at work'. ${ }^{104}$ If we look to the Explanations attached to article 15 of the Charter, there is a clear recognition that the right to work in the Charter derives from the case law on the freedom to pursue an economic activity as a general principle, such as

\footnotetext{
102 Cases C-184/02 and C-223/02 Spain and Finland para 49.

${ }^{103}$ Case C-283/11 Sky Österreich.

${ }^{104}$ Diamond Ashiagbor, 'Article 15' in in Steve Peers and others (eds), The EU Charter of Fundamental Rights $1^{\text {st }}$ ed. (Oxford: Hart, 2014) 423, 426.
} 
Nold. ${ }^{105}$ The Explanations also make clear that the right is quite firmly rooted in the freedom to choose an economic activity found in article 1(2) of the European Social Charter (ESC).

We have seen that both the freedom to conduct a business and the right to work/freedom to choose an occupation have been intertwined since the earliest fundamental rights case law of the CJEU, with the right to choose and practice freely a profession being guaranteed in the context of business freedom. ${ }^{106}$ In those cases, it was recognised that the concepts of freedom to pursue an occupation and freedom to conduct a business are related but distinct. In those early cases, the two rights were also subject to the same limitations. Some authors have gone further, noting that the right to pursue an occupation and the right to run a business are actually the same. As Ashiagbor put it, the right to work has been said to be 'synonymous with unfettered freedom of contract'. ${ }^{107}$ Others have conceived of the right to work as the freedom for individual employees to continue in work despite strike action; in other words, it is a tool for the individual to resist the action of 'powerful' unions. ${ }^{108}$

Not only is the nature of the right to work vague and imprecise, but that its relationship to article 16 is also far from clear. There are two ways of looking at this relationship. Either article 15 is in some way synonymous with article 16 in that it provides workers with a right to autonomy and the freedom to choose an occupation, or it can instead be viewed as opposing the employer's freedom to conduct a business.

If we turn to the case law of the CJEU subsequent to the Charter's enactment, we can see that, to date, it is the former interpretation that has prevailed. In other words, article 15 and article 16 are treated as synonymous. AG Bobek has been particularly extensive in his analysis of the relationship between the provisions. For example, in Fries, the applicant pilot was dismissed when he reached the age of 65 as required by EU law. ${ }^{109}$ This was despite the fact that his existing contract would not expire for a further two months as the statutory pension age was reached at 65 years and two months. For the AG, article 15 'enhances personal autonomy and self-realisation, with human dignity serving as its foundation'. ${ }^{110}$ Due to the restrictive scope

\footnotetext{
105 Case C-4/73 Nold.

${ }^{106}$ Cases C-184/02 and C-223/02 Spain and Finland.

107 Diamond Ashiagbor, 'The Right to Work' in Gráinne de Búrca and Bruno de Witte (eds), Social Rights in Europe (Oxford: OUP, 2005) 241, 258.

${ }^{108}$ Bob Hepple, 'A Right to Work' (1981) 10 ILJ 65, 79.

${ }^{109}$ AG opinion in Case C-190/16 Werner Fries ECLI:EU:C:2017:225.

110 ibid para 66.
} 
of the age limitation, it could not be said to affect adversely the very essence of the right to pursue a freely chosen occupation. ${ }^{111}$

In $\mathrm{Lidl}$, the applicant alleged that poultry labelling requirements infringed both article 15 and article 16. ${ }^{112}$ For AG Bobek, both rights are connected, as is made clear by the CJEU's case law on the general principles. Nevertheless, 'the fact that the Charter today contains two separate provisions suggests that there ought to be some differentiation'. ${ }^{113}$ The AG started by looking at the wording of the two provisions and highlighted that article 16, unlike article 15 is subject to Union law, national laws and practices. This meant that 'Article 16 allows for a broader margin of appreciation when it comes to regulation that might interfere with the freedom to conduct a business'. ${ }^{114}$ From the case law on the general principle, it was also clear that the freedom to conduct a business might be subject to a broad range of interventions on the part of public authorities, which may limit the exercise of economic activity in the public interest. ${ }^{115}$ This led the AG to conclude that there is no doubt that in terms of permissible limitations, 'Article 16 (...) allows for a greater degree of State intervention than Article 15'.116 This statement overlooks the fact that, as we saw, the freedom to choose an occupation was equally restricted in the case law of the CJEU on the general principle. ${ }^{117}$

Turning to the precise nature of the relationship between the two rights, the AG found that both protect individual autonomy in the closely related professional and business fields and that both are linked to the performance of economic activity. ${ }^{118}$ The differences are that article 15 is focused on the element of choice and personal autonomy, with the link to work, emphasising a more relevant impact on natural persons and employment relationships. Article 16 on the other hand focuses on values associated with entrepreneurial activity, such as the freedom of contract. $^{119}$

\section{B. Raising the Right to Work as a Counterweight to Freedom of Contract}

\footnotetext{
111 ibid para 69.

${ }^{112}$ AG opinion in Case C-134/15 Lidl ECLI:EU:C:2016:169.

113 ibid para 22.

114 ibid para 23.

115 ibid.

116 ibid para 25.

${ }^{117}$ Cases C-184/02 and C-223/02 Spain and Finland.

118 ibid.

119 ibid para 26.
} 
The first major hurdle to relying on article 15 is that the CJEU has treated that provision and article 16 as essentially the same. We have also seen that the right to work is potentially composed of a number of different elements. If we start with the right to work as a right to continued employment, it could be argued that the very purpose of the TUD is to ensure that the entire workforce is transferred from the old employer to the new, with minimal exceptions, including the possibility of dismissals for economic, technical or organisational reasons (ETOR). But this is achieved via the Directive itself, with no reference to the right to work. ${ }^{120}$

The rights granted by the TUD/TUPE do appear extensive on their face. Unless one of the exceptions applies, the transferee is liable to the employees 'for everything the transferor has done' 'under or in relation to the relevant contract', for example failure to pay wages or even discriminatory conduct. ${ }^{121}$ It is not difficult to tie these elements into the right to work in the sense that, were the employees treated less favourably upon the transfer, they would be less likely to consent to it. In any event, the protective status granted by the TUD is limited in time. Following the article 16 cases, it is clear that collectively agreed terms only transfer if they were in force at the time of the transfer. The TUD itself at article 3(3) foresees the possibility of restricting the applicability of collectively agreed terms to one-year post transfer. It may be significant to classify transfer rights as fundamental human rights in the guise of article 15 .

I would suggest that the temporal limitations on TUPE rights might give way if subjected to review in light of the Charter. If we look to the approach adopted by the CJEU in the earlier equality law case of Test-Achats, we can see that limitation clauses contained in the legislation were no match for the equality principle expressed as a fundamental right in the Charter. ${ }^{122}$ In cases such as Alemo-Herron, it might have been argued that the term 'on the date of the transfer' should have been more purposively construed to read 'in connection with the transfer'. Alternatively, as happened in Test-Achats, the term could have been overridden entirely given its incompatibility with the Charter. The same is true of the possible restriction of collectively agreed terms to one-year post-transfer.

Another potential way to rely on article 15 is to tie it to the notion of fair work or 'decent work', perhaps in conjunction with article 31(2) of the Charter, which guarantees fair and just conditions at work. It could have been argued in Alemo-Herron that being paid less than their

\footnotetext{
${ }^{120}$ Charles Wynn-Evans, The Law of TUPE Transfers $2^{\text {nd }}$ ed. (Oxford: OUP, 2016) 4.

121 ibid.

122 Case C-236/09 Test-Achats ECLI:EU:C:2011:100.
} 
public sector counterparts (despite having previously been treated in the same way) amounted to degrading treatment. Article 31(2) is probably the Charter provision that has been most successfully invoked to reinforce the protection of employment rights. It has already been used to bolster the CJEU's employee friendly purposive approach to the interpretation of legislation. ${ }^{123}$ It has also been used to ensure that Member States do not renege on their EU employment law commitments. ${ }^{124}$ Article $31(2)$ is drafted in much more precise and forceful language than many of Charter's other provisions and has already been found capable of horizontal direct effect, ie it can be relied on directly in private employment disputes. ${ }^{125}$ The concept of fair and just conditions of work also has a long pedigree as an international right. ${ }^{126}$ Like all Charter rights, the provision is also explicitly linked to the concept of human dignity, as made clear by the Explanations. This connection adds significant normative weight to the idea of fair and just working conditions as a counterpoise to business freedoms.

Perhaps the most promising avenue for counteracting article 16 is, in fact, the aspect of article 15 that has been most prevalent in the case law on the general principle, namely the freedom to choose or pursue an occupation. It was seen in the analysis of the article 15 case law above that the CJEU often treats this aspect of the right to work as essentially synonymous with article 16 , thereby ignoring the former.

In contrast to the CJEU's approach, under the common law dynamic interpretation, the courts have held that:

There is simply no reason why parties should not, if they choose, agree that matters such as remuneration be fixed by processes in which they do not themselves participate. $^{127}$

In other words, both parties, exercising their freedom of contract agreed that remuneration would be set externally. In denying the rights of the employees who in good faith agreed to be so bound, the CJEU in its article 16 jurisprudence was interfering with their freedom of contract and thereby their right to work viewed as an expression of autonomy or freedom. In this respect, the English dynamic approach is more respectful of party autonomy as a whole than that adopted by the CJEU. This also negates AG Bobek's assertion in Lidl that article 16 was

123 Case C-78/11 ANGED ECLI:EU:C:2012:372.

${ }^{124}$ AG opinion in Case C-214/16 King ECLI:EU:C:2017:439.

${ }^{125}$ Cases C-569/16 and C-570/16 Bauer ECLI:EU:C:2018:871 para 54.

${ }^{126}$ Art 2 ESC.

${ }^{127}$ Whent $v$ Cartledge [1997] IRLR 153 EAT (Hicks HHJ) [16]. 
potentially subject to greater limitation than article 15 given that the former right is conditional upon national laws and practices.

On the CJEU's current reading of article 15 as being essentially synonymous with article 16, it is not clear what benefit there is in invoking the right to work to counteract contractual autonomy. This reading would also undermine the possibility of relying on article 15 as an Ungerian counter principle to freedom of contract. But, a more holistic reading of article 15 is possible. As already mentioned above, the Explanations point to the ESC as a source of the right to work. In that instrument, the right to work is a 'core' right and can be found in article 1. The Committee on Social Rights has adopted a common interpretative approach to defining the content of this provision, which can also be seen in the interpretation of the International Covenant on Economic Cultural and Social Rights.

The defining feature of this approach is that, although both instruments couch the right to work in terms of accessibility and availability, this must be read alongside the other labour rights in those instruments, which form part of the general interpretative backdrop to the right to work. This leads to the notion of acceptability of work - ie, decent work. ${ }^{128}$ In the context of the Charter, such an approach could involve reliance on article 15 in conjunction with another Charter provision. Article 31(2) has already been mentioned, but other Charter provisions such as article 30 on the right not to be unfairly dismissed and indeed article 28 on the right to bargain collectively, might equally have a bearing on the outcome of cases involving article 16. As such, we can move from the indeterminate notion of the right to access work to the much more concrete principle that employment should be just and beneficial to the worker. ${ }^{129}$ A similar approach could be adopted to restrict freedom of contract in other regulatory fields.

An additional flaw is that the CJEU's current reading of article 15 completely overlooks the links between that provision and one of the four freedoms of EU law, namely the free movement of workers, which is also set out in the second paragraph of article 15 . Thus, the economic freedoms, which have been found to be part of article 16, can be matched with the equally compelling economic freedom of the worker to access work across the Union. This

\footnotetext{
${ }^{128}$ Colm O’Cinneide, 'The Right to Work in International Human Rights Law' in Virginia Mantouvalou (ed), The Right to Work (Oxford: Hart, 2015) 99, 120-121.

${ }^{129}$ Hugh Collins, 'Is There a Human Right to Work?' in Virginia Mantouvalou (ed), The Right to Work (Oxford: Hart, 2015) 17, 29.
} 
bolsters article 15 's claim to constitutional status and could help to counteract contractual autonomy in cases such as AGET Iraklis.

There are, of course, dangers involved in meeting article 16 on its own terms, accepting that autonomy is an overriding principle to be valued in the employment context, with the only question being whether it is the autonomy of the employer or the worker that prevails on the day. As Deakin notes, 'the right to practice an occupation that has been freely chosen is [only] one step up from [the] liberal conception of a right to market access' ${ }^{130}$ It is altogether possible, therefore, to view the right to work as no more than an extension of the liberal theory of freedom of contract, which reinforces the current balance of the fundamental contradiction rather than reversing it.

\section{Conclusion}

The concept of contractual autonomy as a fundamental right is likely to continue to play a prominent role in future legal and political debate as to the EU's regulatory reach in both the employment context and beyond. In this contribution, we established that there is a complex and as yet underexplored relationship between the general principles of freedom of contract and the freedom to pursue a business and the same concepts found in article 16 of the Charter. The full extent of the relationship is yet to be played out, but what the case law does show is that the idea that the Charter radically departs from existing approaches to contractual autonomy is not so clear-cut. Although the intention of the Charter's drafters was that it would codify the existing general principles, drawing on the notion of contradiction in CLS allowed for a consideration of the wider conflicting values that underpin freedom of contract in EU law. In other words, there is indeed a contradiction, but it is not the contradiction identified in existing commentary.

The added value of CLS is in the clear recognition that any area of the law is likely to involve conflict between contradictory values and it is will not always be possible or desirable to seek an artificial thread unifying or reconciling those values. As such, the quest for coherence between freedom of contract as a general principle and freedom of contract as a fundamental right fails to consider the underlying contradictions in the (any) legal system. Admittedly, the above did attempt to rationalise the two strands of case law doctrinally albeit in a way that

\footnotetext{
${ }^{130}$ Simon Deakin, 'The Right to Work' in Niklas Bruun and others (eds), The European Social Charter and the Employment Relation (Oxford: Hart, 2017) 147.
} 
recognises that it is the individual end of the fundamental contradiction that is now being more explicitly emphasised, with the Charter as a constitutional document further embedding the tilt in favour of the liberal theory of contract law

There are obviously broader constitutional questions that arise from the relationship between the general principles and the Charter, but from a narrower regulatory perspective, this article showed that the confused nature of contractual autonomy as a fundamental right is likely to have wide reaching consequences for the EU's ability to regulate the employment relationship. This is because, although the precise reach of the concept has always been and remains uncertain, contractual autonomy has already been used to displace social rights considerations, allowing them to be viewed as 'restrictions' on the more important business freedoms.

Evidently, there are lessons to be drawn for other fields in which social or non-economic considerations are to be balanced against business rights. Article 16 is therefore likely to be raised more frequently in other regulatory or governance contexts such as consumer law, the monetary union and the Social Pillar. This view is further strengthened by the nascent symbiosis emerging between the Charter and the economic freedoms, which can be described, without exaggeration, as the very foundational core of EU law. Cases such as Viking and Laval have already shown that social considerations faced an uphill struggle to compete with the Union's internal market logic. The market freedoms read in combination with contractual autonomy as a fundamental right are likely to render the balancing of such competing interests altogether more difficult.

The inconsistencies identified in this article show the dangers of relying on contractual autonomy as a regulatory concept. There are so many varied understandings of the principle that it becomes an empty vessel, with multiple meanings. Two solutions to resolving these inconsistencies (at least in the employment context) were advocated in this article. The first was to return to the approach adopted by the CJEU in its earlier case law on the freedom to pursue an economic activity. It was suggested that current arguments as to the relationship between the Charter and the general principles are constitutionally flawed and that there is no legal barrier to the CJEU relying on the general principles in conjunction with the Charter. The second solution was to match freedom of contract as a fundamental right with the freedom to pursue a trade or occupation, in other words, the right to work. The common interpretative approach to the right to work that has been adopted in relation to other social rights instruments should be applied to the Charter, with the right to work being read against the rich backcloth 
of both the Charter's social rights and existing EU employment legislation. Such an approach is consistent with the Explanations to the Charter itself, which point to those other rights instruments as inspiration for the Charter rights. Read in this way, the right to work also has the potential to redress (although not remove according to CLS) the fundamental contradiction within the liberal theory of freedom of contract. 